\title{
Genetic relationships between claw health traits of dairy cows in different parities, lactation stages, and herds with different claw disorder frequencies
}

\author{
D. van der Spek, J. A. M. van Arendonk, and H. Bovenhuis ${ }^{1}$ \\ Animal Breeding and Genomics Centre, Wageningen University, PO 338, $6700 \mathrm{AH}$, Wageningen, the Netherlands
}

\section{ABSTRACT}

Claw disorders affect cow welfare and profitability of farms. Not only claw disorders but also the need for trimming, known as trimming status, has been shown to be heritable. Limited knowledge is available on whether claw health traits (claw disorders and trimming status) are genetically the same trait in different parities, lactation stages, or in herds with low or high frequency of claw disorders. The aim of the current study was to estimate frequencies, heritabilities, and genetic correlations of claw health traits measured in different parities (first vs. later parities), in different lactation stages (early vs. late lactation), and in herds with different frequencies of claw disorders (low vs. high frequency). Analyses revealed that heritabilities measured in different parities, lactation stages, or herds with different trait frequencies are similar for most claw health traits. Also, genetic correlations $\left(r_{g}\right)$ for most claw health traits were not found to be different from unity for traits in different parities, lactation stages, or herds with different trait frequencies. Sole hemorrhage and infectious lesions were genetically different traits in first or later parities $\left(\mathrm{r}_{\mathrm{g}}=0.29 \pm 0.31\right.$ and $0.66 \pm$ 0.15 , respectively). White line separation and infectious lesions were genetically different in early and late lactation $\left(\mathrm{r}_{\mathrm{g}}=0.53 \pm 0.20\right.$ and $0.69 \pm 0.13$, respectively), and sole ulcer was genetically different in herds with low or high frequency of sole ulcer $\left(\mathrm{r}_{\mathrm{g}}=0.75 \pm 0.14\right)$. In our analysis, we did not find convincing evidence to supports the use of multiple trait models for the analysis of claw health traits treating them as different traits in different parities, lactation stages, and herds with different claw disorder frequency.

Key words: foot health, Holstein, genetic correlation

Received March 11, 2015.

Accepted May 20, 2015.

${ }^{1}$ Corresponding author: henk.bovenhuis@wur.nl

\section{INTRODUCTION}

The importance of claw health in dairy cattle is well known: claw disorders affect cow welfare and profitability of farms. Studies showed that up to about $70 \%$ of cows presented for claw trimming have at least 1 claw disorder (Manske et al., 2002; van der Waaij et. al., 2005; van der Spek et al., 2013). Bruijnis et al. (2012) showed that claw disorders have a substantial effect on the cow's welfare. Financial consequences are mainly due to losses in milk production, increased fertility problems, and early culling (Enting et al., 1997; Bruijnis et al., 2010). The average cost in the Netherlands was estimated to be $\$ 95$ for a single clinical claw disorder and $\$ 18$ for a subclinical claw disorder (Bruijnis et al., 2010).

Many studies have found claw disorders to be heritable (e.g., Gernand et al., 2012; Oberbauer et al., 2013; van der Spek et al., 2013) and concluded that the incidence of claw disorders can be reduced by genetic selection. The need for trimming, termed trimming status, is an interesting novel trait for claw health and has been shown to be heritable (van der Spek et al., 2013). For several traits, such as milk production and fertility, genetic parameters in first-parity cows differ from those in later-parity cows (Banos and Shook, 1990; Roxström et al., 2001), or genetic parameters differ within parity at different lactation stages (Tijani et al., 1999). Little is known about genetic parameters for claw health traits (claw disorders and trimming status) in first and later parities or early and late lactation. Metabolic factors, such as high-concentrate diets (Manson and Leaver, 1987, 1988a,b), restricting forage or dry hay (Livesey and Fleming, 1984; Groehn et al., 1992), calving and the onset of lactation (Webster, 2001; Tarlton et al., 2002), are known to increase the susceptibility to claw disorders. Collard et al. (2000) found an association between high metabolic load and laminitis. As metabolic load has an effect on the development of claw disorders, claw disorders may be genetically different traits in first (when the animal is still growing) or later parities and in early or late lactation. Some studies estimated heritabilities of claw disorders based on first-parity records 
only (Smit et al., 1986; Laursen et al., 2009; Buch et al., 2011). Other studies combined records from multiple parities to estimate heritabilities (e.g., van der Waaij et al., 2005; Häggman and Juga, 2013; van der Spek et al., 2013). Harder et al. (2006) found a higher heritability in first parity as compared with first and later parities together for a combined claw and leg disease trait. van der Linde et al. (2010) showed that the genetic correlation between first and later parities for digital dermatitis, sole ulcer and interdigital hyperplasia were significantly different from unity. van der Linde et al. (2010) also showed that heritabilities differed between parities for some claw disorders. Gernand et al. (2013) showed that genetic correlations were high for the same claw disorders among test-days from mid lactation (50-350 d) but low between early $(0-50 \mathrm{~d})$ and late lactation (>305 d).

Bishop and Woolliams (2010) argued that heritabilities for disease resistance are higher under specific environmental conditions where the animal is able to express resistance to disease. Genetic selection might be more effective based on records collected on herds with higher frequencies of claw disorders. In high-frequency herds, cows are more likely to express their resistance to claw disorders. Richardson et al. (2014) found a higher heritability for susceptibility to bovine tuberculosis (bTB) for herds with a higher bTB prevalence. Furthermore, Richardson et al. (2014) found genetic correlations different from unity for susceptibility to bTB between environments that differed in bTB herd prevalence. Calus et al. (2006) found similar results for SCS across herds with different mean bulk tank SCS. For claw health traits, it is unknown whether they are the same traits in herds with different trait frequency. The aim of the current study was to estimate frequencies, heritabilities, and genetic correlations of claw health traits measured in different parities (first vs. later parities), in different lactation stages (early vs. late lactation), and in herds with different frequencies of claw health traits (low vs. high frequency).

\section{MATERIALS AND METHODS}

\section{Data}

The initial data set contained 67,213 Holstein Friesian cows with at least 1 claw trimming record. Cows with both parents unknown or with 2 different trimming records on the same date were removed (it is likely that these records are mistakes, as cows are not normally trimmed twice on the same day). Observations with missing parity or lactation stage were removed as well. The final data set contained 44,317 cows, of which 24,133 cows had at least 1 claw trimming record; the other cows were present in the herds at time of trimming but were not trimmed themselves. The 24,133 trimmed cows had a total number of claw trimming records of 35,966 . The farmer decided if and when cows were to be trimmed. As a result, not all cows present in a herd were trimmed during a routine visit of the claw trimmers. At least 2 cows were trimmed during a herd visit. Data were collected by 12 professional claw trimmers, employed by 2 claw-trimming organizations, from January 2007 until May 2014 during routine visits to 655 dairy farms in France. Claw disorders were recorded for the hind legs and scored as a binary trait: $0=$ no claw disorder, and $1=$ claw disorder in at least one hind leg. Recorded claw disorders used in the current study were double sole (DS), interdigital hyperplasia (IH), sole hemorrhage (SH), sole ulcer (SU), white line separation (WLS), and a combination of infectious lesions (DER) consisting of (inter-)digital dermatitis and heel horn erosion. The trait trimming status indicates whether a cow was trimmed (score 1) or not trimmed (score 0) during a visit by the claw trimmer. The claw disorders and the trait trimming status are explained in more detail by van der Spek et al. (2013).

\section{Statistical Analyses}

The frequency of each claw disorder in trimmed cows was calculated as the number of cows with a claw disorder divided by the total number of trimmed cows $(\mathrm{n}=24,133)$. Note that not all cows were presented for trimming. However, for untrimmed cows it was not known whether they had a claw disorder or not. The frequency of trimming status indicates how many cows were trimmed of the total number of cows present at the time of trimming.

The following linear animal model was used for univariate and bivariate analyses:

$$
\mathrm{Y}_{\mathrm{ijklm}}=\mu+\mathrm{H}_{\mathrm{i}}+\mathrm{YS}_{\mathrm{j}}+\mathrm{P}_{\mathrm{k}}+\mathrm{L}_{\mathrm{l}}+\text { Animal }_{\mathrm{m}}+\mathrm{e}_{\mathrm{ijk} k \mathrm{~m}}
$$

where $\mathrm{Y}_{\mathrm{ijklm}}$ is a claw disorder; $\mu$ is the overall mean; $\mathrm{H}_{\mathrm{i}}$ is the fixed effect of herd $\mathrm{i}(\mathrm{i}=1$ to 655$)$; $\mathrm{YS}_{\mathrm{j}}$ is the fixed effect of year-season of trimming $\mathrm{j}$ (season is defined as spring $=$ March-May, summer = June-August, autumn $=$ September-November, winter $=$ December February); $\mathrm{P}_{\mathrm{k}}$ is the fixed effect of the kth parity $(\mathrm{k}=$ $1,2,3$, and $\geq 4) ; \mathrm{L}_{1}$ is the fixed effect of the lth lactation stage at trimming $(1=1$ to 10 , group 1 to 9 are $50 \mathrm{~d}$ each, with the first group from 1 to $50 \mathrm{~d}$, the second group from 50 to $100 \mathrm{~d}$, and so on; cows with lactation stage $\geq 450 \mathrm{~d}$ were combined in group 10); Animal $_{\mathrm{m}}$ is the random additive genetic effect of the mth cow $\sim N\left(0, \mathbf{A} \sigma_{a}^{2}\right)$, where $\mathbf{A}$ is the additive genetic relation- 
ships matrix among animals; and $\mathrm{e}_{\mathrm{ijklm}}$ is the random residual effect $\sim N\left(0, \mathbf{I} \sigma_{e}^{2}\right)$, where $\mathbf{I}$ is the identity matrix. The pedigree consisted of 175,972 animals. Heritability was calculated as

$$
\mathrm{h}^{2}=\frac{\sigma_{a}^{2}}{\sigma_{a}^{2}+\sigma_{e}^{2}},
$$

where $\sigma_{a}^{2}=$ the additive genetic variance and $\sigma_{e}^{2}=$ the residual variance. Analyses were performed using ASReml (Gilmour et al., 2009). Genetic correlations were estimated using bivariate analyses. If a genetic correlation significantly differed from one, the traits were considered to be genetically different. The significance of nonunity genetic correlations was tested by constraining the genetic correlation to 0.99 and comparing the likelihood of this model to that of the unconstrained model with a log-likelihood ratio test $($ LRT): LRT = $-2 \times\left[\log \mathrm{L}\left(\mathrm{H}_{0}\right)-\log \mathrm{L}\left(\mathrm{H}_{\mathrm{a}}\right)\right]$, where $\mathrm{H}_{0}$ indicates the constrained model (i.e., traits are genetically the same) and $\mathrm{H}_{\mathrm{a}}$ indicates the unconstrained model and LRT $\sim \chi_{1}^{2}$. A genetic correlation was significantly different from 1 when $P<0.05$.

\section{First Parity Versus Later Parities}

To investigate whether a claw disorder (or trimming status) in first and later parity is genetically identical, cows were divided in first and later parity and analyzed using a bivariate analysis. Only the first observation of each cow for first and later parities was used.

The number of trimmed cows in first parity was 11,029 and the number of cows in later parities was 16,585 . The total number of cows in first parity, including untrimmed cows, was 25,231 , and in later parities the total number of cows was 28,765 . The average number of cows trimmed per herd was 40 in first parity and 52 in later parities.

\section{Early Lactation Versus Late Lactation}

To investigate whether the same claw disorder (or trimming status) measured during early or late lactation were genetically identical, cows were divided into groups based on the number of days in lactation at the time of trimming. Early lactation was defined as 0 to $149 \mathrm{~d}$ in lactation and late lactation was defined as 150 to $305 \mathrm{~d}$ in lactation. Only the first observation in early or late lactation was used. The number of trimmed cows during early lactation was 11,300 and during late lactation was 11,139 cows. The average number of cows trimmed per herd was 39 for early lactation and was 37 for late lactation. The number of cows with a record for trimming status during early lactation was 24,637 and during late lactation was 33,200.

\section{Low Versus High Frequency}

Herds were divided in low- and high-frequency groups of a specific claw disorder or trimming status to investigate whether the same trait measured in herds with a low and high frequency are genetically identical. Only the first observation for each cow was used. Low frequency was defined for each trait separately, in such a way that the number of animals in the low group was approximately equal to the number of animals in the high group. In general, low cows were below average herd frequency of a specific claw disorder and high cows were above average. In the low and high groups, the average number of cows trimmed per herd ranged from 32 to 47 for different claw disorders, with an average of 36 for low and 39 for high.

\section{RESULTS}

\section{First Parity Versus Later Parities}

Table 1 shows the frequencies of claw disorders and trimming status in first and later parities. The frequency of IH and WLS increased substantially from first to later parities. The frequency of IH increased from 5.7 to $11.1 \%$ and the frequency of WLS increased from 10.8 to $20.5 \%$. The frequency of $\mathrm{SH}$ decreased from $28.3 \%$ in first parity to $19.3 \%$ in later parities. In first parity, $43.6 \%$ of the cows were trimmed and in later parities $57.7 \%$ of the cows were trimmed.

For most traits, heritabilities were the same in first and later parities (Table1). The heritability of IH increased from first to later parities. The IH had a heritability of $0.05( \pm 0.01)$ in first parity, which increased to $0.12( \pm 0.02)$ in later parities. The heritability of WLS and DER decreased from $0.06( \pm 0.01)$ in first parity to $0.04( \pm 0.01)$ in later parities. Heritabilities from univariate and bivariate analyses were similar (results not shown).

Table 1 also shows genetic correlations and the $P$ value of the LRT, indicating whether the genetic correlation is significantly different from 1 . The genetic correlation between first and later parities did not significantly differ from one for DS, IH, WLS, SU, and trimming status. A genetic correlation between first and later parities of $0.29( \pm 0.31)$ was estimated for $\mathrm{SH}$ and a genetic correlation of $0.66( \pm 0.15)$ for DER. Both correlations were significantly $(P<0.05)$ different from 
Table 1. Frequencies and heritabilities (estimated with bivariate models) of claw disorders and trimming status in first and later parities ${ }^{1}$

\begin{tabular}{|c|c|c|c|c|c|c|}
\hline \multirow[b]{2}{*}{ Trait } & \multicolumn{2}{|c|}{ Frequency (\%) } & \multicolumn{2}{|c|}{ Heritability } & \multirow[b]{2}{*}{$\mathrm{rg}_{\mathrm{g}}^{2}$} & \multirow[b]{2}{*}{$P$-value } \\
\hline & Parity 1 & Parity $\geq 2$ & Parity 1 & Parity $\geq 2$ & & \\
\hline Double sole & 9.0 & 13.0 & 0.02 & 0.03 & $0.49 \pm 0.25$ & 0.06 \\
\hline Infectious lesions & 37.5 & 34.0 & 0.06 & 0.04 & $0.66 \pm 0.15$ & 0.02 \\
\hline Interdigital hyperplasia & 5.7 & 11.1 & 0.05 & 0.12 & $0.99 \pm 0.09$ & 1.00 \\
\hline Sole hemorrhage & 28.3 & 19.3 & 0.01 & 0.02 & $0.29 \pm 0.31$ & $<0.001$ \\
\hline Sole ulcer & 8.6 & 7.6 & 0.07 & 0.06 & $0.96 \pm 0.08$ & 0.73 \\
\hline White line separation & 10.8 & 20.5 & 0.06 & 0.04 & $1.00 \pm 0.08$ & 1.00 \\
\hline Trimming status & 43.6 & 57.7 & 0.02 & 0.02 & $0.66 \pm 0.21$ & 0.96 \\
\hline
\end{tabular}

${ }^{1}$ Claw disorder frequency is defined as the percentage of cows with a disorder out of the total number of cows trimmed. For trimming status, the frequency indicates the proportion of animals trimmed. Standard errors for heritabilities were 0.01 or 0.02 .

${ }^{2}$ Genetic correlation $\left(\mathrm{r}_{\mathrm{g}}\right)$ of the same trait in first and later parities and $P$-values to test whether $\mathrm{r}_{\mathrm{g}}$ is $<1$.

1. For DS. a genetic correlation of $0.49( \pm 0.25)$ was found. However, this correlation was not significantly different from one $(P=0.06)$.

\section{Early Lactation Versus Late Lactation}

Table 2 shows the frequencies of claw disorders and trimming status during early and late lactation. Frequencies of claw disorders were generally similar in early and late lactation. The largest differences were found for WLS and SH. The WLS increased from $15.2 \%$ in early lactation to $18.2 \%$ in late lactation, whereas $\mathrm{SH}$ decreased from $28.5 \%$ in early lactation to $21.5 \%$ in late lactation. For trimming status, a large difference was found. During early lactation $45.9 \%$ of the cows were trimmed and during late lactation $33.6 \%$ of the cows were trimmed.

Heritabilities estimated from univariate and bivariate analyses were similar (results not shown). Table 2 shows that heritabilities were similar during early and late lactation. Heritabilities for the different disorders ranged from 0.01 to 0.09 and the largest absolute difference between early and late lactation was 0.02 for IH, SU, and WLS.

Table 2 also shows the genetic correlation and $P$ value of the LRT for each claw disorder and trimming status. A genetic correlation between early and late lactation of $0.69( \pm 0.13)$ was found for DER and a genetic correlation of $0.53( \pm 0.20)$ was found for WLS; both were significantly lower than 1 . The genetic correlation between early and late lactation was not significantly different from 1 for DS, IH, SH, and SU.

\section{Low Versus High Frequency}

The overall frequency and the frequency and number of cows in low- and high-frequency groups of each claw disorder in trimmed cows and of trimming status are shown in Table 3. The overall frequency ranged from 8.2 (SU) to $33.9 \%$ (DER) for trimmed cows, and $54.5 \%$

Table 2. Frequencies and heritabilities (estimated with bivariate models) of claw disorders and trimming status during early (0 to 149 DIM) and late (150 to 305 DIM) lactation

\begin{tabular}{|c|c|c|c|c|c|c|}
\hline \multirow[b]{2}{*}{ Trait } & \multicolumn{2}{|c|}{ Frequency $^{1}(\%)$} & \multicolumn{2}{|c|}{ Heritability $^{2}$} & \multirow[b]{2}{*}{$\mathrm{r}_{\mathrm{g}}{ }^{3}$} & \multirow[b]{2}{*}{$P$-value } \\
\hline & Early & Late & Early & Late & & \\
\hline Double sole & 11.2 & 13.0 & 0.01 & 0.01 & $0.82 \pm 0.21$ & 0.35 \\
\hline Infectious lesions & 37.5 & 35.3 & 0.04 & 0.04 & $0.69 \pm 0.13$ & $<0.001$ \\
\hline Interdigital hyperplasia & 8.7 & 9.5 & 0.07 & 0.09 & $0.99 \pm 0.08$ & 0.32 \\
\hline Sole hemorrhage & 28.5 & 21.5 & 0.02 & 0.03 & $0.94 \pm 0.35$ & 0.89 \\
\hline Sole ulcer & 8.8 & 9.8 & 0.05 & 0.07 & $0.99 \pm 0.07$ & 1.00 \\
\hline White line separation & 15.2 & 18.2 & 0.04 & 0.02 & $0.53 \pm 0.20$ & $<0.001$ \\
\hline Trimming status & 45.9 & 33.6 & $\mathrm{NC}^{4}$ & $\mathrm{NC}$ & $\mathrm{NC}$ & - \\
\hline \multicolumn{7}{|c|}{$\begin{array}{l}{ }^{1} \text { Claw disorder frequency in trimmed cows only. For trimming status the frequency indicates the proportion } 0 \\
\text { animals trimmed. }\end{array}$} \\
\hline \multicolumn{7}{|c|}{${ }^{2}$ Standard errors for heritabilities were 0.01 or 0.02} \\
\hline \multicolumn{7}{|c|}{$\begin{array}{l}{ }^{3} \text { Genetic correlation }\left(\mathrm{r}_{\mathrm{g}}\right) \text { of the same trait during early and late lactation and } P \text {-values to test whether } \mathrm{r}_{\mathrm{g}} \\
\text { lower than } 1 \text {. }\end{array}$} \\
\hline
\end{tabular}


Table 3. Frequencies per trait and subdivision in herds with low and high frequencies of a particular claw disorder or trimming status ${ }^{1}$

\begin{tabular}{|c|c|c|c|c|c|c|c|c|}
\hline Trait & $\begin{array}{c}\text { Frequency }^{2} \\
(\%)\end{array}$ & $\begin{array}{c}\text { Cut-off }^{3} \\
(\%)\end{array}$ & \multicolumn{2}{|c|}{ Frequency $^{2}[\%$ (no.)] } & \multicolumn{2}{|c|}{ Heritability $^{4}$} & $\mathrm{r}_{\mathrm{g}}{ }^{5}$ & $P$-value \\
\hline Double sole & 11.4 & 10 & $4.9(12.432)$ & $18.2(11.701)$ & 0.01 & 0.01 & $0.99 \pm 0.77$ & 1.00 \\
\hline Interdigital hyperplasia & 8.4 & 6 & $2.4(11.826)$ & $14.2(12.307)$ & 0.04 & 0.14 & $0.82 \pm 0.12$ & 0.15 \\
\hline Sole hemorrhage & 23.3 & 22 & $9.9(12.270)$ & $37.2(11.863)$ & 0.02 & 0.01 & $0.99 \pm 0.48$ & 1.00 \\
\hline Sole ulcer & 8.2 & 7 & $3.2(12.566)$ & $13.6(11.567)$ & 0.04 & 0.08 & $0.75 \pm 0.14$ & 0.03 \\
\hline
\end{tabular}

${ }^{1}$ The number of cows in low and high frequency herds is indicated together with the heritabilities (estimated with bivariate models) of claw disorders and trimming status.

${ }^{2}$ Claw disorder frequency in trimmed cows only. For trimming status the frequency indicates the proportion of animals trimmed.

${ }^{3}$ Cut-off value; herds with a trait frequency below this value were assigned to the low-frequency group and a frequency equal or higher are assigned to the high-frequency group.

${ }^{4}$ Standard errors for heritabilities were 0.01 or 0.02 .

${ }^{5}$ Genetic correlation $\left(\mathrm{r}_{\mathrm{g}}\right)$ of the same trait in low and high frequency herds and $P$-values to test whether $\mathrm{r}_{\mathrm{g}}$ is lower than 1.

of the cows were trimmed. The cut-off value to divide herds in low and high groups ranged from a herd average of 6 (IH) to $35 \%$ (DER). The average frequency of claw disorders in trimmed cows in the low group ranged from $2.4(\mathrm{IH})$ to $16.3 \%$ (DER). The average frequency of claw disorders in trimmed cows in the high group ranged from 13.6 (SU) to $55.2 \%$ (DER). On average, $24.1 \%$ of the cows were trimmed in the low group and $79.7 \%$ of the cows were trimmed in the high group.

Heritabilities estimated from univariate and bivariate analyses were similar (results not shown). For most traits, heritabilities were similar in low and high groups (Table 3). Both IH and SU had a lower heritability in the low group (both 0.04) as compared with the high group (0.14 and 0.08 , respectively).

Table 3 also shows the genetic correlation and $P$ value of the LRT in the low and high groups. For SU, a genetic correlation of $0.75( \pm 0.14)$ between low and high was found, which was significantly different from 1. For all other traits, the genetic correlations between low and high were not significantly different from 1 .

\section{DISCUSSION}

\section{First Versus Later Parities}

The frequency of claw disorders in trimmed cows was higher in first parity for some traits (SH, DER, SU) and higher in later parities for other traits (DS, IH, WLS). The frequencies for claw disorders were based on trimmed cows only and, therefore, might be biased. The frequency of trimming status was higher in later parities. When untrimmed cows were included, and assumed to have no claw disorders, frequencies for all claw disorders were higher in later parities except for $\mathrm{SH}$. A higher frequency or risk for $\mathrm{SH}$ in first parity was also found in previous studies (Manske et al., 2002; Sogstad et al., 2005).

Genetic parameters were estimated using a linear animal model for the analysis of binomial traits. It is well documented that heritabilities from these models are frequency dependent; a threshold model accounts for differences in frequencies (Gianola, 1982). However, threshold models are computationally more demanding and can result in convergence issues (Misztal et al., 1989). In our study, we also experienced convergence issues. When the threshold model did converge, it was shown by Boettcher et al. (1999) and Luo et al. (2001) that biased estimates were obtained for herd-year variances and additive genetic effects. Genetic correlations estimated with linear or threshold models are theoretically expected to be similar (Gianola, 1982), which was also shown empirically by simulation (Mäntysaari et al., 1991) and using field data (Mao, 1976). Therefore, in the current study, a linear animal model was used to calculate genetic parameters.

Heritabilities (Table 1) seemed to be different between parities for SH, WLS, and IH, but this could be due to a difference in frequency of claw disorders. The frequency of SH was higher in first parity, whereas the frequency of IH and WLS was higher in later parities. When we used a threshold model to estimate heritabilities, on the underlying scale and thereby accounting for a difference in frequency, most heritabilities were similar in first and later parities (results not shown) except for SH. On the underlying scale, the heritability for $\mathrm{SH}$ in first parity was $0.03( \pm 0.02)$ and in later parities was $0.07( \pm 0.02)$.

Genetic correlations were estimated between claw disorders in first and later parities. Convergence of the model could not be reached when claw disorders were analyzed as 3 different traits (parity 1, 2, and $\geq 3$ ). 
Both SH and DER were found to be genetically different traits when measured in first or later parities (Table 1), suggesting these traits are influenced by different genes in first or later parities. van der Linde et al. (2010) found digital dermatitis, SU, and IH to be genetically different traits in first and later parities. Digital dermatitis was not included in our analysis as a separate trait, but was combined with heel erosion and interdigital dermatitis in the trait DER. In our study, DER was also found to be genetically different in first or later parities. We showed that WLS was genetically the same trait in first and later parities, which was also shown by van der Linde et al. (2010).

Cows undergo strong physiological changes during the onset of lactation, after first calving. Several traits related to the physiology of the cow have been found to be genetically different traits in first and later parities, such as calving ease (Luo et al., 2002) and gestation length (Eaglen et al., 2012). Lisscher and Ossent (2002) indicated that fat tissue in the digital cushion of the claw develops during first parity. They indicated that heifers have less fat tissue in the digital cushion, which may cause the cushions to be more vulnerable for SH. This might be one reason why $\mathrm{SH}$ is genetically different when measured in first or later parities.

In our study, we also found infectious lesions (DER) to be genetically different in first and later parities. This finding is in line with findings for other infectious traits, such as mastitis or SCS, which were shown to be genetically different in first and later parities (Pösö and Mäntysaari, 1996; Banos and Shook, 1990; Carlén et al., 2004).

\section{Early Lactation Versus Late Lactation}

Heritabilities during early and late lactation were similar, except for a small difference for IH, SU, and WLS. Gernand et al. (2013) also indicated that heritability estimates for claw disorders were relatively stable from 50 to 305 DIM. They also found that genetic correlations among different test days were close to 1 from 50 to $305 \mathrm{~d}$ in lactation. A low correlation was found between test days from early $(0-50 \mathrm{~d})$ or late $(>305$ d) lactation and mid lactation (50-305 d). Gernand et al. (2013) argued that this could be due to the low number of observations before d 50 and after d 305 combined with the use of a random regression model. Genetic correlations were estimated between claw disorders in early and late lactation. In our study, DER and WLS were genetically different during early and late lactation, indicating an influence of different genes. Convergence of the model could not be reached when claw disorders were analyzed as 3 different traits (early, mid, and late lactation). van Knegsel et al. (2007) showed that a negative energy balance during early lactation affects innate immune function and this can influence the development of infectious diseases. Schöpke et al. (2013) found that a lower BCS, indicating a lower energy balance, was associated with a higher prevalence of digital dermatitis in first-parity cows. In our study, DER is a combination of infectious claw disorders including digital dermatitis. Frequency of DER in trimmed cows was slightly higher in early lactation as compared with later lactation, indicating a lower energy balance during early lactation.

During the first part of the lactation, cows experience an increased metabolic load due to recovery from parturition and increasing production combined with a slower increase in feed intake. A high metabolic load often results in a negative energy balance, which reaches a peak at around $100 \mathrm{~d}$ in lactation. When the animal is not able to adapt adequately and enters negative energy balance (e.g., by mobilizing body reserves), this can result in metabolic disorders such as ketosis (Gillund et al., 2001) and milk fever (Roche and Berry, 2006). Collard et al. (2000) showed that laminitis was unfavorably associated with measures of energy balance. Negative energy balance occurs in early lactation and may be the reason why the genetic correlation of the metabolic disorder WLS was significantly different between early or late lactation. Other metabolic claw disorders (SH, DS, SU) did not show a significant difference during early or late lactation.

\section{Low Versus High Frequency}

Except for SU, claw disorders and trimming status were genetically identical traits when measured in herds with a low or high disorder frequency. For IH and SU, the heritability was higher in herds with a high disorder frequency; for trimming status, the opposite was found. However, when heritabilities were calculated with a threshold model taking the differences in disorder frequency into account, heritability estimates were similar in low- or high-frequency herds. Based on these results, we concluded that collecting data from herds with different disorder frequency levels does not influence genetic parameters for most traits. Bishop and Woolliams (2010), however, indicated that a higher disease frequency results in a higher heritability due to more animals being exposed to factors triggering the disease. We did not observe that in our study, which could be due to the groups not being extreme enough.

Genetic correlations were estimated between claw disorders in low- and high-claw disorder frequency herds. Convergence of the model could not be reached when claw disorders were analyzed as 3 different traits (low, medium, high frequency). In addition, the true 
claw disorder frequency is not known, as not all animals were trimmed. Less untrimmed cows were found in lowcompared with high-frequency herds (24.1 vs. $79.7 \%$, respectively). The average difference between low- and high-frequency herds was $20.7 \%$, but with untrimmed cows included, assuming they had no claw disorders, the average difference dropped to $9.8 \%$. Perhaps herds should be divided in low- and high-frequency herds based on frequencies including untrimmed cows. However, it is not clear whether untrimmed cows really did not have claw disorders. Scoring all cows in all herds would overcome this problem by identifying the true frequencies and may lead to higher heritability estimates for high-frequency herds. It may also lead to a rearrangement of herds in high or low frequency groups. Even though heritability corrected for frequencies were similar in low- or high-frequency herds, SU was found to be a genetically different trait. With an average of $3.2 \%$ of SU in low-frequency herds, this group had a quite extreme frequency among the low group.

\section{Application}

Some claw disorders were found to be different traits when measured in different parities or lactation stages or in herds with low- or high-claw disorder frequency. The difference of $\mathrm{SH}$ in first and later parities was highly significant. For DER and WLS, the difference was highly significant between early or late lactation. A multitrait model could be used to estimate genetic parameters and breeding values for traits that are significantly different from unity. In a multitrait model, claw disorders scored in different parities or lactation stages can be treated as separate traits. Another option could be the use of a random regression model for genetic evaluation, but many parameters need to be estimated (Jensen, 2001). A single-trait model, for example treating claw disorders in first and later parities as the same trait, is easier to implement as compared with a multitrait model. A single-trait model may still be preferred if genetic correlations between for example claw disorders measured in first and later parities are high (e.g., above 0.90). In our analysis, we did not find convincing evidence that supports the use of multitrait models for the analysis of claw health traits in different parities, lactation stages, and herd frequency levels.

\section{CONCLUSIONS}

The current study shows that most claw disorders and trimming status are genetically the same trait in different parities, lactation stages, or herds with low- or high-claw disorder frequency. Digital dermatitis and heel horn erosion was found to be a genetically differ- ent trait in first and later parities and in early and late lactation. Sole hemorrhage was genetically different in first and later parities, WLS was genetically different in early and late lactation, and SU was genetically different in herds with a low- or high-sole ulcer frequency. The current study is the first to investigate whether trimming status is genetically the same trait in different parities, lactation stages, and in herds with a different frequency of trimmed animals. Overall, around 50\% of the cows were trimmed and no genetic differences were found due to parity or frequency of trimming in the herd.

\section{ACKNOWLEDGMENTS}

Our study was financially supported by Genes Diffusion, Douai, France. The authors thank all the people involved (claw trimmers, technicians, and farmers) for their major effort in collecting data and making it available for us.

\section{REFERENCES}

Banos, G., and G. E. Shook. 1990. Genotype by environment interaction and genetic correlations among parities for somatic cell count and milk yield. J. Dairy Sci. 73:2563-2573.

Bishop, S. C., and J. A. Woolliams. 2010. On the genetic interpretation of disease data. PLoS ONE 5:e8940.

Boettcher, P. J., L. K. Jairath, and J. C. M. Dekkers. 1999. Comparison of methods for genetic evaluation of sires for survival of their daughters in the first three lactations. J. Dairy Sci. 82:1034-1044.

Bruijnis, M. R. N., B. Beerda, H. Hogeveen, and E. N. Stassen. 2012. Assessing the welfare impact of foot disorders in dairy cattle by a modeling approach. Animal 6:962-970.

Bruijnis, M. R. N., H. Hogeveen, and E. N. Stassen. 2010. Assessing economic consequences of foot disorders in dairy cattle using a dynamic stochastic simulation model. J. Dairy Sci. 93:2419-2432.

Buch, L. H., A. C. Sørensen, J. Lassen, P. Berg, J. A. Eriksson, J. H. Jakobsen, and M. K. Sørensen. 2011. Hygiene-related and feedrelated hoof diseases show different patterns of genetic correlations to clinical mastitis and female fertility. J. Dairy Sci. 94:1540-1551.

Calus, M. P. L., L. L. G. Janss, and R. F. Veerkamp. 2006. Genotype by environment interaction for somatic cell score across bulk milk somatic cell count and days in milk. J. Dairy Sci. 89:4846-4857.

Carlén, E., E. Strandberg, and A. Roth. 2004. Genetic parameters for clinical mastitis, somatic cell score, and production in the first three lactations of Swedish Holstein cows. J. Dairy Sci. 87:30623070 .

Collard, B. L., P. J. Boettcher, J. C. M. Dekkers, D. Petitclerc, and L. R. Schaeffer. 2000. Relationships between energy balance and health traits of dairy cattle in early lactation. J. Dairy Sci. 83:2683-2690.

Eaglen, S. A., M. P. Coffey, J. A. Woolliams, and E. Wall. 2012. Evaluating alternate models to estimate genetic parameters of calving traits in United Kingdom Holstein-Friesian dairy cattle. Genet. Sel. Evol. 44:23.

Enting, H., D. Kooij, A. A. Dijkhuizen, R. B. M. Huirne, and E. N. Noordhuizen-Stassen. 1997. Economic losses due to clinical lameness in dairy cattle. Livest. Prod. Sci. 49:259-267.

Gernand, E., D. A. Döhne, and S. König. 2013. Genetic background of claw disorders in the course of lactation and their relationships with type traits. J. Anim. Breed. Genet. 130:435-444.

Gernand, E., P. Rehbaein, U. U. von Borstel, and S. König. 2012. Incidences of and genetic parameters for mastitis, claw disorders, 
and common health traits recorded in dairy cattle contract herds. J. Dairy Sci. 95:2144-2156.

Gianola, D. 1982. Theory and analysis of threshold characters. J. Anim. Sci. 54:1079-1096.

Gillund, P., O. Reksen, Y. T. Grohn, and K. Karlberg. 2001. Body condition related to ketosis and reproductive performance in Norwegian dairy cows. J. Dairy Sci. 84:1390-1396.

Gilmour, A. R., B. J. Gogel, B. R. Cullis, and R. Thompson. 2009. ASReml User Guide Release 3.0. VSN International Ltd. Hemel Hempstead, UK.

Groehn, J.A., J.B. Kaneene, and D. Foster. 1992. Risk factors associated with lameness in lactating dairy cattle in Michigan. Prev. Vet. Med. 14:77-85.

Häggman, J., and J. Juga. 2013. Genetic parameters for hoof disorders and feet and leg conformation traits in Finnish Holstein cows. J. Dairy Sci. 96:3319-3325.

Harder, B., J. Bennewitz, D. Hinrichs, and E. Kalm. 2006. Genetic parameters for health traits and their relationship to different persistency traits in German Holstein dairy cattle. J. Dairy Sci. 89:3202-3212.

Jensen, J. 2001. Genetic evaluation of dairy cattle using test-day models. J. Dairy Sci. 84:2803-2812.

Laursen, M. V., D. Boelling, and T. Mark. 2009. Genetic parameters for claw and leg health, foot and leg conformation, and locomotion in Danish Holstein. J. Dairy Sci. 92:1770-1777.

Lisscher, Ch. J., and P. Ossent. 2002. Pathogenesis of sole lesions attributed to laminitis in cattle. Pages 82-89 in Proc. 12th Int. Symp. Lameness in Ruminants, Orlando, FL. Organizing Committee, Orlando, FL.

Livesey, C. T., and F. L. Fleming. 1984. Nutritional influences on laminitis, sole ulcer and bruised sole in Friesian cows. Vet. Rec. 114:510-512.

Luo, M. F., P. J. Boettcher, L. R. Schaeffer, and J. C. M. Dekkers. 2001. Bayesian inference for categorical traits with an application to variance component estimation. J. Dairy Sci. 84:694-704.

Luo, M. F., P. J. Boettcher, L. R. Schaeffer, and J. C. M. Dekkers, 2002. Estimation of genetic parameters of calving ease in first and second parities of Canadian Holsteins using Bayesian methods. Livest. Prod. Sci. 74:175-184.

Manske, T., J. Hultgren, and C. Bergsten. 2002. Prevalence and interrelationships of hoof disorders and lameness in Swedish dairy cows. Prev. Vet. Med. 54:247-263.

Manson, F. J., and J. D. Leaver. 1987. Effect of concentrate to silage ratio and hoof trimming on lameness in dairy-cows. Anim. Prod. 44:469.

Manson, F. J., and J. D. Leaver. 1988a. The influence of concentrate amount on locomotion and clinical lameness in dairy cattle. Anim. Prod. 47:185-190.

Manson, F. J., and J. D. Leaver. 1988b. The influence of dietary protein intake and of hoof trimming on lameness in dairy cattle. Anim. Prod. 47:191-199.

Mäntysaari, E. A., R. L. Quaas, and Y. T. Gröhn. 1991. Simulation study on covariance component estimation for two binary traits in an underlying continuous scale. J. Dairy Sci. 74:580-591.

Mao, I. L. 1976. Correlation estimates from discontinuous data. J. Dairy Sci. 59:2115-2121.

Misztal, I., D. Gianola, and J. L. Foulley. 1989. Computing aspects of a nonlinear method of sire evaluation for categorical data. J. Dairy Sci. 72:1557-1568.
Oberbauer, A. M., S. L. Berry, J. M. Belanger, R. M. McGoldrick, J. M. Pinos-Rodriquez, and T. R. Famula. 2013. Determining the heritable component of dairy cattle foot lesions. J. Dairy Sci. 96:605-613.

Pösö, J., and E. A. Mäntysaari. 1996. Relationships between clinical mastitis, somatic cell score, and production for the first three lactations of Finnish Ayrshire. J. Dairy Sci. 79:1284-1291.

Richardson, I. W., D. G. Bradley, I. M. Higgins, S. J. More, J. McClure, and D. P. Berry. 2014. Variance components for susceptibility to Mycobacterium bovis infection in dairy and beef cattle. Genet. Sel. Evol. 46:77.

Roche, J. R., and D. P. Berry. 2006. Periparturient climatic, animal, and management factors influencing the incidence of milk fever in grazing systems. J. Dairy Sci. 89:2775-2783.

Roxström, A., E. Strandberg, B. Berglund, U. Emanuelson, and J. Philipsson. 2001. Genetic and environmental correlations among female fertility traits and milk production in different parities of Swedish Red and White dairy cattle. Acta Agric. Scand. A Anim. Sci. 51:7-14.

Schöpke, K., S. Weidling, R. Pijl, and H. H. Swalve. 2013. Relationships between bovine hoof disorders, body condition traits, and test-day yields. J. Dairy Sci. 96:679-689.

Smit, H., B. Verbeek, D. J. Peterse, J. Jansen, B. T. McDaniel, and R. D. Politiek. 1986. Genetic aspects of claw disorders, claw measurements and 'type' scores for feet in Friesian cattle. Livest. Prod. Sci. 15:205-217.

Sogstad, A. M., T. Fjeldaas, and O. Østeras. 2005. Lameness and claw disorders of the Norwegian Red Dairy Cattle housed in free stalls in relation to environment, parity and stage of lactation. Acta Vet. Scand. 46:203-217.

Tarlton, J. F., D. E. Holah, K. M. Evans, S. Jones, G. R. Pearson, and A. J. F. Webster. 2002. Biomechanical and histopathological changes in the support structures of bovine hooves around the first time of calving. Vet. J. 163:196-204.

Tijani, A., G. R. Wiggans, C. P. Van Tassell, J. C. Philpot, and N. Gengler. 1999. Use of (co)variance functions to describe (co)variances for test day yield. J. Dairy Sci. 82:226.e1-226.e14.

van der Linde, C., G. de Jong, E. P. C. Koenen, and H. Eding. 2010. Claw health index for Dutch dairy cattle based on claw trimming and conformation data. J. Dairy Sci. 93:4883-4891.

van der Spek, D., J. A. M. Van Arendonk, A. A. A. Vallée, and H. Bovenhuis. 2013. Genetic parameters for claw disorders and the effect of preselecting cows for trimming. J. Dairy Sci. 96:6070-6078.

van der Waaij, E. H., M. Holzhauer, E. Ellen, C. Kamphuis, and G. de Jong. 2005. Genetic parameters for claw disorders in Dutch dairy cattle and correlations with conformation traits. J. Dairy Sci. 88:3672-3678.

van Knegsel, A. T. M., G. de Vries Reilingh, S. Meulenberg, H. van den Brand, J. Dijkstra, B. Kemp, and H. K. Parmentier. 2007. Natural antibodies related to energy balance in early lactation dairy cows. J. Dairy Sci. 90:5490-5498.

Webster, A. J. F. 2001. Effects of housing and two forage diets on the development of claw horn lesions in dairy cows at first calving and in first lactation. Vet. J. 162:56-65. 